\title{
The species of Aspona Stål and nomenclatural notes (Hemiptera, Cicadomorpha, Membracidae) ${ }^{1}$
}

\author{
Albino M. Sakakibara ${ }^{2,3}$ \\ ${ }^{1}$ Contribution $\mathrm{n}^{\circ} 1567$ of the Departamento de Zoologia, Universidade Federal do Paraná. \\ ${ }^{2}$ Departamento de Zoologia, Universidade Federal do Paraná. Caixa Postal 19020, 81531-980 Curitiba-PR, Brazil. sakaki@bsi.com.br \\ ${ }^{3} \mathrm{CNPq}$ fellowship.
}

\begin{abstract}
The species of Aspona Stål and nomenclatural notes (Hemiptera, Cicadomorpha, Membracidae). The genus Aspona Stål contains now only two species: A. bullata Stål, 1862 (= Aspona gibosa Fonseca \& Diringshofen, 1969 syn. nov. = Taunaya gibbosa Remes-Lenicov, 1973 syn. nov.) and A. quadrinodosa (Fonseca \& Diringshofen, 1969) comb. nov. (formerly in Cyphotes Burmeister).
\end{abstract}

KEYWORDS. Auchenorrhyncha; Darninae; Homoptera; nomenclatural acts; taxonomy.

RESUMO. As espécies de Aspona Stål e notas nomenclaturais (Hemiptera, Cicadomorpha, Membracidae). O gênero Aspona Stål passa a ter apenas duas espécies: A. bullata Stål, 1862 (= Aspona gibosa Fonseca \& Diringshofen, 1969 syn. nov. = Taunaya gibbosa Remes-Lenicov, 1973 syn. nov.) e A. quadrinodosa (Fonseca \& Diringshofen, 1969) comb. nov. (antes em Cyphotes Burmeister).

PALAVRAS-CHAVE. Atos nomenclaturais; Auchenorrhyncha; Darninae; Homoptera; taxonomia.

Stål (1862) described the genus including in it only one species from Brazil-Rio de Janeiro, Aspona bullata.

Fowler (1894) added three species from Mexico and Panama: A. turgescens, A. intermedia, and A. cuneata. About the species he stated: "In our collection there are specimens of three species, one of which belongs to the typical form, and the second is intermediate and passes on to the third, which any one would describe as a new genus without the least hesitation, were it not for the second; after considerable doubt I have come to the conclusion that it is best to class them together under Aspona until more is known regarding the group, which seems to be a very scarce one."

In the catalogue of McKamey (1998), six species are listed: A. aspera (Walker, 1858), A. bullata Stål, 1862, A. cuneata Fowler, 1894, A. gibosa Fonseca \& Diringshofen, 1969, A. intermedia Fowler, 1894, and A. turgescens Fowler, 1894.

Of these species, in the present paper, only A. bullata and A. gibosa remain in Aspona. The others will be treated in a separate paper.

The genus Aspona Stål is classified in Darninae-Darnini as defined by Deitz (1975).

Abbreviations: DZUP - Departamento de Zoologia, Universidade Federal do Paraná, Curitiba-PR, Brazil; MLPAMuseo de La Plata, La Plata, Argentina; ZMUC - Universitets Zoologisk Museum, Copenhagen, Denmark.

\section{Aspona Stål, 1862}

Aspona Stål, 1862: 29 (type species: Aspona bullata Stål, 1862, by monotypy); McKamey, 1998: 149.
Stål (1862) defined the genus as: "Head triangular subobtuse, sub-projected. Thorax at each side just behind lateral angles projected, their angles sub-prominent, then backwards behind middle gradually widened, rounded at each side and posteriorly tapered, longer than abdomen, convex, apex subacute. Tegmina in great part covered by thorax, longitudinal veins very approximate to costal margin, five apical cells, oblong or sub-oblong, and one sub-triangular discoidal cell situated between second and third longitudinal veins just before the two internal apical cells. Legs simple, tarsi subequal in length." He also compared with Oxygonia Fairmaire, 1846 [= Gelastogonia Kirkaldy, 1904] and Cyphotes Burmeister, 1835 , saying that it is much more alike the second but differing by the characters of head and tegmina.

One of the characteristics given by Stål (1862) was the presence of one discoidal cell in the tegmina. Coincidentally, in A. gibosa Fonseca \& Diringshofen, Taunaya gibbosa Remes-Lenicov, Cyphotes quadrinodosa Fonseca \& Diringshofen, and also in the specimen of A. bullata here examined, only one discoidal cell was observed, the internal one (the external cell disappears because the transversal vein $\mathrm{s}$ is missing). Then, we consider it as a good character, though much more material is needed to confirm the constancy of this type of venation.

Aspona bullata Stål, 1862

Figs. 1-2

Aspona bullata Stål, 1862: 29 (type loc.: Brazil, Rio de Janeiro); Metcalf \& Wade, 1965: 618; Deitz, 1975: 70; McKamey, 1998: 150 . 

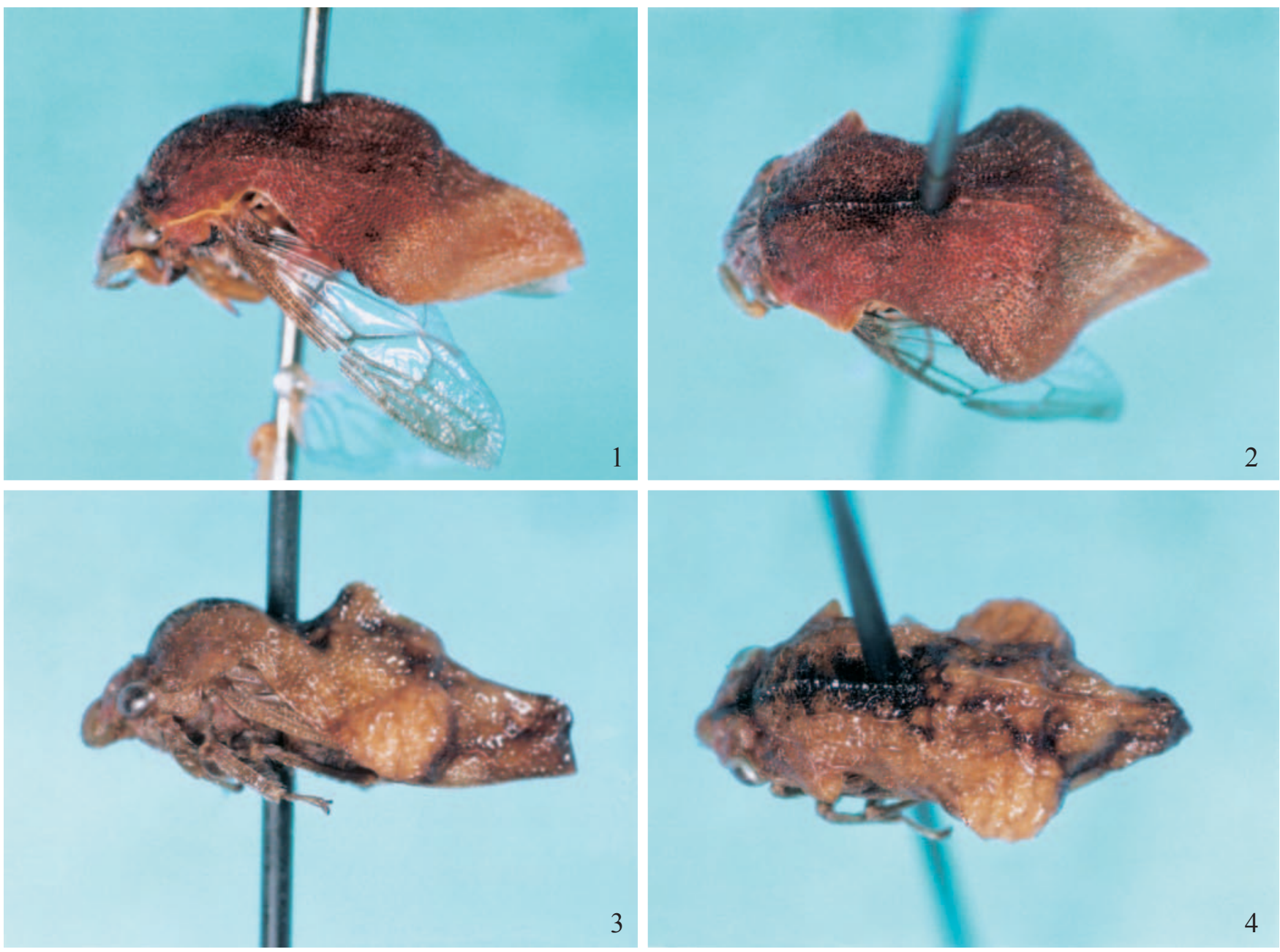

Figs. 1-4. Species of Aspona Stål (lateral and dorsal views): 1-2, A. bullata Stål, 1862 (male); 3-4, A. quadrinodosa (Fonseca \& Diringshofen, 1969) (female).

Aspona gibosa Fonseca \& Diringshofen, 1969: 154, fig. 8 (type loc.: Brazil, Santa Catarina: Rio Vermelho); McKamey, 1998: 150. Syn. nov.

Taunaya gibbosa Remes-Lenicov, 1973: 137 (type loc.: Argentina, Misiones); McKamey, 1998: 155. Syn. nov.

Stål (1862) described the species based on a male specimen, from Rio de Janeiro, characterizing as follows: "Yellowish-olive, thorax densely punctate, obscurely subferrugineous at disc, with median percurrent carina, paler and distinct, at each side provided with many irregular and furcate carinae; head and legs at underside blackish. B\&. Long. $6^{1 / 3}$, Lat. $3^{1 / 4}$ Mill.”

Fonseca \& Diringshofen (1969) proposed a new species, Aspona gibosa. The type material, a female specimen, was collected in Santa Catarina, Rio Vermelho.

Remes-Lenicov (1973) described Taunaya gibbosa, a species from Argentina, Misiones. The type material consisted of three female specimens. In the comments about the species, she declared: "Close to T. rugosa Fonseca; it differs by the uniform coloration of head and metopidium, the greater size, and the dorsal protuberance; the surface of pronotum less rugose; the humeral angles acute and also by the type of venation."

Both the species, Aspona gibosa Fonseca \& Diringshofen, 1969 and Taunaya gibbosa Remes-Lenicov, 1973, though classified in distinct genus, they actually belong in Aspona Stål. Morphologically they differ slightly from $A$. bullata Stål. This difference, however, is due to the sex: the first two were based on females, and the last one on male. They are, then, considered here as new synonyms.

Material examined. BRAZIL. Santa Catarina: Benedito Novo, 1 male (DZUP).

A photograph of syntype of Aspona bullata Stål, 1862 (ZMUC).

A photograph of Taunaya gibbosa Remes-Lenicov, 1973 (MLPA).

Aspona quadrinodosa (Fonseca \& Diringshofen, 1969) comb. nov.

Figs. 3-4

Cyphotes quadrinodosos [sic] Fonseca \& Diringshofen, 1969: 155 (type loc.: Brazil, Santa Catarina: Rio Vermelho). 
Cyphotes quadrinodosus [sic] Fonseca \& Diringshofen, 1969: 156; McKamey, 1998: 150.

The species was based on a female specimen collected in Santa Catarina, Rio Vermelho, the same locality of Aspona gibosa Fonseca \& Diringshofen.

A. quadrinodosa is very similar to A. bullata, especially in dorsal view; it differs, however, in the surface of pronotum which is more sculptured, and the raised lines irregularly disposed. It is transferred to Aspona because of the morphology and the type of tegmina venation, i. e., presenting one discoidal cell.

Material examined. BRAZIL. Santa Catarina: Nova Teutônia, 1 female (DZUP).

\section{REFERENCES}

Deitz, L. L. 1975. Classification of the higher categories of the New World treehoppers (Homoptera: Membracidae). North Carolina Agricultural Experiment Station Technical Bulletin, Raleigh, 225: $1-177$.

Fonseca, J. P. da \& R. V. Diringshofen. 1969. Contribuição ao conhecimento dos membracídeos neutrópicos (Homoptera: Membracidae, VI). Arquivos do Instituto Biológico, São Paulo, 36: $143-161$.

Fowler, W. W. 1894. Order Rhynchota. Suborder HemipteraHomoptera. (Cont.). Biologia Centrali-Americana, London, 2: $25-56$.

McKamey, S. H. 1998. Taxonomic catalogue of the Membracoidea (exclusive of leafhoppers): second supplement to fascicle I Membracidae of the General Catalogue of the Hemiptera. Memoirs of the American Entomological Institute, Gainesville, 60: 1377.

Remes-Lenicov, A. M. M. de. 1973. Una especie nueva de Taunaya (Homoptera-Membracidae). Revista de la Sociedad Entomologica Argentina, Buenos Aires, 34: 137-139.

Stål, C. 1862. Bidrag till Rio Janeiro-traktens Hemipter-fauna. II. Öfversigt af Svenska Vetenskaps-Akademiens Förhandlingar, Stockholm, 3: 1-75. 